\title{
ISOLATION, PURIFICATION, AND OPTIMIZATION OF THERMOPHILIC AND ALKALIPHILC PROTEASE ORIGINATING FROM HOT WATER SPRING BACTERIA
}

\author{
ASHWINI N PUNTAMBEKAR, MANJUSHA S DAKE*
}

Protein Biochemistry Laboratory, Dr. D. Y. Patil Biotechnology and Bioinformatics Institute, Dr. D. Y. Patil Vidyapeeth, Pune - 411 033, Maharashtra, India. Email: manjusha.dake@dpu.edu.in

Received: 05 April 2017, Revised and Accepted: 31 May 2017

\section{ABSTRACT}

Objective: The main objective of this study is to investigate the industrial applications of a thermophillic alkaline protease from a hot water spring bacterial isolate " $\mathrm{A}$ " and to study its production, optimization, and purification.

Methods: The alkaline protease was produced using shake flask studies maintaining a $\mathrm{pH}$ of 9.0 and a temperature of $50^{\circ} \mathrm{C}$. 0 ptimization studies of the enzyme were carried out using variable $\mathrm{pH}$, temperature, organic carbon, and nitrogen sources followed by purification of the enzyme using DEAE-cellulose ion exchange chromatography technique. Stability of the enzyme was analyzed in the presence of organic solvents and surfactants. The efficiency of the enzyme in the removal of proteinaceous stains in the presence of strong detergents under extreme conditions was assessed. The fibrinolytic activity of the enzyme in dissolving the blood clot was confirmed.

Results: The isolated alkaline protease was purified to homogeneity with a 16 -fold increase. Media optimization studies revealed that $1 \%$ glucose and $1 \%$ casein-induced the production of alkaline protease. The purified enzyme retained stability in the presence of ethanol, methanol, and acetone and surfactants such as $0.5 \%(\mathrm{w} / \mathrm{v})$ sodium dodecyl sulfate (SDS) and $0.5 \%(\mathrm{v} / \mathrm{v})$ Triton-X-100. The isolated alkaline protease successfully removed the proteinaceous stains and showed significant results in the dissolution of blood clot.

Conclusion: The above experimental results confirm that the isolated enzyme has both thermophilic and alkaliphilic protease properties. Thereby the enzyme finds promising industrial applications even in extreme conditions.

Keywords: Protease, Thermophillic, Alkaliphillic, Purification, Applications

(C) 2017 The Authors. Published by Innovare Academic Sciences Pvt Ltd. This is an open access article under the CC BY license (http://creativecommons. org/licenses/by/4. 0/) DOI: http://dx.doi.org/10.22159/ajpcr.2017.v10i9.19717

\section{INTRODUCTION}

Proteases (EC 3.4.2.1), are the protein hydrolyzing enzymes and constitute a large group of industrially important enzymes. They catalyze the cleavage of peptide bonds in proteins. Based on their mechanism of action proteases are divided as endopeptidases and exopeptidases. The exopeptidases act only near the terminal amino or carboxyl position. Endopeptidases are further categorized as serine, cysteine, aspartate, and metallopeptidases based on their catalytic mechanism. Bacterial proteases are the most significant [1] and account for nearly $60 \%$ of the total worldwide enzyme sales [2,3]. Aeromonas, Alcaligenes, Arthrobacter, Bacillus, Halomonas, Pseudomonas, and Serratia are the major bacterial genera which contribute to proteases. Bacterial alkaline proteases, are specialized due to their higher activity under alkaline $\mathrm{pH}$ range (6-13) specialized and broad substrate specificity. Most of the alkaline proteases have active serine center, whereas some others are of a metallo-type where metal ions contribute to enhanced activity and stability at higher temperatures [4]. Enhanced thermostability was observed for alkaline proteases from Bacillus sp., Streptomyces sp., and Thermus sp. after the addition of $\mathrm{CaCl}_{2}$ [5]. Serine proteases find industrial importance [6]. Thermal stability and activity at alkaline $\mathrm{pH}$ ensures applications of alkaline protease in detergent formulation [7]. Studies have revealed that bacteria capable of producing alkaline proteases have keratinolytic activity [8]. Alkaline proteases have wide-scale industrial applications including food processing, leather processing as a dehairing agent, textile industry, diagnostic reagents, household waste management, recovery of silver from X-ray film, and bioremediation $[9,10]$. Proteases have wide applications in many industries, namely, detergents, and food processing, especially for cheese ripening, meat tenderization, animal nutrition, pharmaceutics, paper industry, and food industry [11].
Microbial proteases have immense applications as compared to other hydrolytic enzymes in various spheres of science and industries and there is a high demand of alkaline protease in detergent industries which make it as a potent enzyme [12]. Insoluble fibrous keratin protein is the primary substance found in chicken feathers, and cannot be degraded by common proteases. Keratinases belong to the group of extracellular serine proteases capable of degrading keratin [13].

Thermophilic bacteria from hot water springs produce unique thermostable enzymes where proteases originating from such bacterial species are of particular interest due to their wide range of commercial applications [14-16].

Very few reports are available on the bacterial enzymes showing both thermophilic and alkaliphilic nature. Therefore, the present work aims to study the biotechnological and industrial applications of a thermophilic alkaline protease isolated from hot water spring in the removal of proteinaceous stains and its medicinal importance as a fibrinolytic agent. Production of enzyme to a significant extent was achieved using wheat bran as a cheaper agro based residues. Entire study aims to carry out production, optimization, and purification of the isolated alkaline protease enzyme.

\section{METHODS}

\section{Isolation of thermophilic strain}

Water and soil samples were collected from hot spring region near Mumbai (Maharashtra, India) in sterile containers and transported to laboratory and maintained at $4^{\circ} \mathrm{C}$ microorganisms were isolated from collected soil and water samples using nutrient agar plates $(\mathrm{pH} 7.0)$ by serial dilution technique. Plates were incubated at $37^{\circ} \mathrm{C}$ and $50^{\circ} \mathrm{C}$ for 
24-48 h. Pure cultures for seven bacterial isolates (A, B, C, D, E, F, and G) obtained as individual colonies were screened for the production of alkaline protease using skim milk agar ( $\mathrm{pH} 9.0$ ) which were incubated at $50^{\circ} \mathrm{C}$ for $24-48 \mathrm{~h}$. Isolates showing maximum zone of hydrolysis, maximum $\mathrm{pH}$, and temperature tolerance were further selected for production of alkaline protease by submerged fermentation process. The biochemical characterization was performed for selected bacterial isolates.

\section{Production of protease by submerged fermentation process}

The production media $(\mathrm{pH} 7.0 ; \mathrm{pH} 9.0)$ comprising glucose $0.1 \%$, peptone $1 \%$, yeast extract $0.02 \%\left(\mathrm{w} / \mathrm{v}\right.$ ), $\mathrm{MgSO}_{4} 0.01 \%(\mathrm{w} / \mathrm{v}), \mathrm{CaCl}_{2} 0.5 \%$ $(\mathrm{w} / \mathrm{v})$, and $\mathrm{FeSO}_{4} .7 \mathrm{H}_{2} \mathrm{O} 0.01 \%(\mathrm{w} / \mathrm{v})$, were inoculated using all seven bacterial isolates (A, B, C, D, E, F, and G) and incubated at $37^{\circ} \mathrm{C}$ and $50^{\circ} \mathrm{C}$ in a shaking incubator (Remi, Thane, Maharashtra, India) maintained at $150 \mathrm{rpm}$. Media were harvested after 24, 48, and $72 \mathrm{~h}$ and centrifuged $\left( \pm 4^{\circ} \mathrm{C}\right)$ at $8000 \mathrm{rpm}$ for $15 \mathrm{~min}$. Supernatant derived from the bacterial culture served as a source of extracellular protease.

Selected bacterial isolates with higher activity were used further for optimization of enzyme production under variable $\mathrm{pH}$ and temperature conditions.

\section{Protease assay}

Protease activity was determined by following the regular assay method using casein as a substrate [17]. The protease activity was assayed by incubating $1 \mathrm{ml}$ of the enzyme with $2.5 \mathrm{ml}$ of $1 \%(\mathrm{w} / \mathrm{v}$ ) casein (prepared in $100 \mathrm{mM}$ sodium phosphate buffer; $\mathrm{pH} 7.0$ and $100 \mathrm{mM}$ Tris- $\mathrm{HCl}$ buffer; $\mathrm{pH} 9.0$ ) at $37^{\circ} \mathrm{C}$ for 30 minutes. Reaction was terminated by adding $2.5 \mathrm{ml}$ tricarboxylic acid (TCA). TCA soluble fraction containing soluble peptides was measured using the Lowry method [18] by referring the standard curve of tyrosine $(0-100 \mu \mathrm{g} / \mathrm{ml})$.

One unit activity of alkaline protease is the amount of enzyme required to liberate $1.0 \mu \mathrm{M}$ of tyrosine under optimized conditions of $\mathrm{pH}$ and temperature.

\section{Optimization of $\mathrm{pH}$ and temperature for the production of alkaline protease}

The effect of variable $\mathrm{pH}(7.0,8.0,9.0$, and 10.0) on the production of alkaline protease was analyzed using selected bacterial isolates " $A$ " and "D" at $37^{\circ} \mathrm{C}$ and $50^{\circ} \mathrm{C}$. Isolates were grown in the production media for 24-72 h incubation period. The caseinolytic activity of enzyme was measured after every $24 \mathrm{~h}$ using the standard assay procedure mentioned as above.

\section{Optimization of enzyme production using agricultural residues}

Production of alkaline protease was analyzed using agricultural residues as wheat bran, rice husk and maize, and chick pea powder collected from local markets. Minimal media (disodium hydrogen phosphate $-3 \%$, potassium dihydrogen phosphate $1.5 \%$, ammonium chloride $0.5 \%$, sodium chloride $0.25 \%$, and calcium chloride $0.001 \%$ ) supplemented with $1 \%(\mathrm{w} / \mathrm{v})$ different agricultural were used for bacterial growth using isolates (A, B, C, D, and F) and production of enzyme. The inoculated media $(\mathrm{pH} 9.0)$ were incubated further at $50^{\circ} \mathrm{C}$ for 24,48 , and $72 \mathrm{~h}$ and the activity of enzyme was analyzed.

Optimization of enzyme production using variable carbon sources The production of protease was analyzed using variable carbon sources such as glucose, lactose, maltose, dextrose, and starch at $1 \%(\mathrm{w} / \mathrm{v})$ concentration. The carbon sources were autoclaved separately and then added to the production medium. Growth of bacterial isolates and subsequent production of enzyme was monitored at $\mathrm{pH} 9.0$ and a temperature of $50^{\circ} \mathrm{C}$ after 24,48 , and $72 \mathrm{~h}$. The caseinolytic assay was performed and the activity was recorded.

Optimization of enzyme production using variable nitrogen sources

The production of protease was analyzed using variable organic nitrogen sources such as yeast extract, peptone, beef extract, and casein at $1 \%$ $(\mathrm{w} / \mathrm{v})$ concentration in the production medium. Growth of bacterial isolates and subsequent production of enzyme was monitored at $\mathrm{pH} 9.0$ and a temperature of $50^{\circ} \mathrm{C}$ after 24,48 , and $72 \mathrm{~h}$. The caseinolytic assay was performed and the activity was recorded.

\section{Effect of variable buffers on enzyme activity}

The stability of protease was analyzed using variable buffers (tris $\mathrm{NaOH}$, Carbonate-bicarbonate, Glycine- $\mathrm{NaOH}$, and Borax) with $\mathrm{pH}=9.0$ at $50^{\circ} \mathrm{C}$ for $24 \mathrm{~h}$. The enzyme was preincubated along with buffers for $1 \mathrm{~h}$. The activity of protease without buffer was considered $100 \%$. The residual proteolytic activity was measured.

\section{Effect of organic solvents and surfactants on the activity of alkaline protease}

The stability of alkaline protease from isolate " $\mathrm{A}$ " was analyzed in the presence of $5 \%(\mathrm{v} / \mathrm{v})$ of different organic solvents (hexane, methanol, isopropanol, ethanol, toluene, dimethyl sulfoxide (DMSO), and acetone), $0.5 \%$ and $1 \%(\mathrm{w} / \mathrm{v})$ of surfactants such as (sodium dodecyl sulfate [SDS], Triton X-100, and Tween-80) and hydrogen peroxide as an oxidizing agent $\left(\mathrm{H}_{2} \mathrm{O}_{2}\right)$. The enzyme was preincubated along with solvents, surfactants, and oxidizing agents for $1 \mathrm{~h}$. The activity of protease without solvent, surfactant, and the oxidizing agent was considered $100 \%$. The residual proteolytic activity was measured.

\section{Purification of alkaline protease}

The cultural supernatant derived from isolate " $\mathrm{A}$ " containing alkaline protease activity was subjected to partial purification using $80 \%$ ammonium sulfate fractionation. The precipitated proteins were separated by centrifugation of extract at 10,000 rpm for 20 minutes. Resultant precipitate was dissolved in Tris buffer (0.02 M, pH 9.0) and dialyzed extensively against the same buffer for $48 \mathrm{~h}$. The resultant dialysate was used for estimation of enzyme activity and specific activity.

Alkaline protease was further purified by ion exchange chromatography using DEAE-cellulose and CM-cellulose. The activated ion exchanger was repeatedly washed with buffer. Both DEAE-cellulose and CM-cellulose columns were equilibrated with $50 \mathrm{mM}$ Tris- $\mathrm{HCl}$ of $\mathrm{pH} 9.0$.

Dialyzed enzyme solution was applied to the DEAE-cellulose $(1.5 \mathrm{~cm} \times 50 \mathrm{~cm})$ and eluted by applying continuous stepwise gradient of 0.5-1 M NaCl using same equilibration buffer. Fractions each of $4 \mathrm{ml}$ were collected along with a flow rate of $25 \mathrm{ml} / \mathrm{h}$. Fractions containing enzyme activity were pooled together, dialyzed and analyzed for enzyme activity and total protein content.

\section{Applications of alkaline protease}

\section{Compatibility with commercial detergents}

The compatibility of the isolated alkaline protease was analyzed using a blood stained cloth with dimensions 2 " $\times 2$ ". Blood stained cloth was treated with $1 \mathrm{ml}$ of isolated alkaline protease along with detergent solution $(7 \mathrm{mg} / \mathrm{ml}$ ) in one container and only with detergent solution separately in another one. A control set was prepared by treating blood stained cloth only with distilled water in a third container.

\section{Blood clot dissolution studies}

Blood sample was collected from the blood bank. A volume of $0.5 \mathrm{ml}$ of venous blood sample was added in preweighed sterile tubes and allowed to stand at for $45 \mathrm{~min}$ at $37^{\circ} \mathrm{C}$ for the formation of blood clot. Serum was removed, and the tubes were again weighed to determine the actual weight of the clot. Clots were further subjected to the action of $0.5 \mathrm{ml}$ and $1.0 \mathrm{ml}$ of partially purified enzyme. A control set was prepared by replacing the enzyme solution with distilled water. The tubes were further incubated for $90 \mathrm{~min}$ at $37^{\circ} \mathrm{C}$ to observe the lysis of blood clots. The remnant fluid was removed, and the tubes were weighed. The difference in weight taken before and after lysis of the clot was measured in terms of \% of clot lysis. 


\section{RESULTS AND DISCUSSION}

\section{Isolates showing maximum zone of inhibition}

Morphologically distinct bacterial colonies isolated from soil and water samples from hot water spring through repeated streaking on nutrient agar plates were subjected to extensive screening for the production of alkaline protease using skim milk agar $(\mathrm{pH} 9.0)$. Five bacterial isolates (A, B, C, D, and E) showing maximum zone of hydrolysis revealed production of extracellular alkaline protease. Growth of bacterial isolates at alkaline $\mathrm{pH}$ of 9.0 and at a temperature of $50^{\circ} \mathrm{C}$ indicated their thermophilic and alkaliphilic nature.

Selected isolates were used further for the optimization of alkaline protease production using liquid medium provided with carbon and nitrogen source (Table 1)

\section{Optimization of alkaline protease production}

The production of alkaline protease is affected by fermentation parameters such as $\mathrm{pH}$ and temperature, incubation time, and media composition with variable source carbon in the form of metabolizable sugars, organic solvents, and surfactants. Maximization in the production of alkaline protease from selected alkaliphilic and thermophilic bacterial isolates is essential to reveal their industrial applications. Further work was carried out for optimization of alkaline protease production using media with variable compositions and cultivation conditions.

\section{Effect of incubation period $\left(\mathrm{pH} 7.0 ; 37^{\circ} \mathrm{C}\right)$}

Incubation period affects the production of alkaline protease by bacterial isolates and is simultaneously influenced by other parameters including physical factors as $\mathrm{pH}$, temperature, inoculum size, and metabolic state of the cell. The data regarding the production of protease under variable incubation period from $24-72 \mathrm{~h}$ is revealed in Fig. 1. All the bacterial isolates produced a maximum titer of protease after an incubation period of $72 \mathrm{~h}$. Maximum protease production was recorded for isolates "A" and "D" (250 U/ml and $218 \mathrm{U} / \mathrm{ml})$. Isolates "B" and "C" have been reported to show maximal protease activity of $172 \mathrm{U} / \mathrm{ml}$ and $202 \mathrm{U} / \mathrm{ml}$ after $72 \mathrm{~h}$ of incubation. The protease production recorded for isolates "E," "F," and "G" was $174 \mathrm{U} / \mathrm{ml}, 143 \mathrm{U} / \mathrm{ml}$, and $134 \mathrm{U} / \mathrm{ml}$, respectively. Maximum growth and enzymes production were recorded after $72 \mathrm{~h}$ of incubation [19-21].

Production of alkaline protease was carried out at $37^{\circ} \mathrm{C}$ in the medium comprising glucose $0.1 \%$, peptone $1 \%$, yeast extract $0.02 \%(\mathrm{w} / \mathrm{v})$, $\mathrm{MgSO}_{4}$ 0.01\% (w/v), $\mathrm{CaCl}_{2} 0.5 \%(\mathrm{w} / \mathrm{v}), \mathrm{FeSO}_{4} \cdot 7 \mathrm{H}_{2} \mathrm{O} 0.01 \%(\mathrm{w} / \mathrm{v})$, at $\mathrm{pH} 7.0$ for variable time intervals of 24,48 , and $72 \mathrm{hrs}$. Values are presented as mean \pm standard deviation (SD) of three independent experiments.

\section{Effect of incubation period $\left(\mathrm{pH} 9.0 ; 37^{\circ} \mathrm{C}\right)$}

Fig. 2 also displayed similar results where enzyme production increased linearly with increase in incubation time from 24-72 h. Maximum enzyme production was observed for all isolates at $72 \mathrm{~h}$ incubation period. Higher yield of the enzyme was revealed for all isolates after growth in the production media maintained at an alkaline $\mathrm{pH}$ of 9.0. The

Table 1: Promising isolates showing maximum protease activity on skim milk agar

\begin{tabular}{ll}
\hline Isolates & Zone of hydrolysis $\mathbf{( c m )}$ \\
\hline Isolate A & $2.5 \pm 0.2$ \\
Isolate B & $1.5 \pm 0.4$ \\
Isolate C & $1.8 \pm 0.7$ \\
Isolate D & $2.3 \pm 0.3$ \\
Isolate E & $1.6 \pm 0.6$ \\
Isolate F & $1.5 \pm 0.7$ \\
Isolate G & $1.8 \pm 0.6$ \\
\hline
\end{tabular}

Zone of hydrolysis indicates the protease producing ability of bacterial isolates.

All values are expressed as mean \pm SD of three independent experiments.

SD: Standard deviation activity of alkaline protease was maximal for isolates "A" $(223 \mathrm{U} / \mathrm{ml})$ and "D" (208 U/ml) followed by "B" (186 U/ml) and "C" (199 U/ml). Thus, bacteria produce higher enzyme during stationary growth phase while the enzyme produced by them is alkaline in nature. Similar observations were made for protease produced from Bacillus sp. using wheat bran and groundnut cake [22].

Production of alkaline protease was carried out at $37^{\circ} \mathrm{C}$ in medium comprising glucose $0.1 \%$, peptone $1 \%$, yeast extract $0.02 \%(\mathrm{w} / \mathrm{v})$, $\mathrm{MgSO}_{4} 0.01 \%(\mathrm{w} / \mathrm{v}), \mathrm{CaCl}_{2} 0.5 \%(\mathrm{w} / \mathrm{v}), \mathrm{FeSO}_{4} 7 \mathrm{H}_{2} \mathrm{O} 0.01 \%(\mathrm{w} / \mathrm{v}$ ), at $\mathrm{pH} 9.0$ for variable time intervals of 24,48 , and $72 \mathrm{~h}$. Data represent mean \pm SD of three independent sets of observations.

\section{Effect of incubation period $\left(\mathrm{pH} 9.0 ; 50^{\circ} \mathrm{C}\right)$}

The influence of the higher temperature of $50^{\circ} \mathrm{C}$ and alkaline $\mathrm{pH}$ of 9.0 on the production of alkaline protease by all six bacterial isolates was evaluated at $50^{\circ} \mathrm{C}$ and $\mathrm{pH}$ 9.0. Maximal production of alkaline protease was observed for the bacterial isolates "A" and "D" as $232 \mathrm{U} /$ $\mathrm{ml}$ and $191 \mathrm{U} / \mathrm{ml}$, respectively, at $72 \mathrm{~h}$ incubation. This was followed by isolates "B" and "C" with a subsequent yield of protease $163 \mathrm{U} / \mathrm{ml}$ and $151 \mathrm{U} / \mathrm{ml}$, respectively. Results explicit the alkaline and thermophilic nature of bacterial isolates where " $\mathrm{A}$ " and " $\mathrm{D}$ " being promising one were further selected for purification and biochemical characterization. This suggested that the bacterial strain was alkaliphillic in nature and optimum $\mathrm{pH}$ range between 9.0 and 10.0 for growth and enzymes production is a common feature among alkaliphillic organisms (Fig. 3) [11].

Production of alkaline protease was carried out at $50^{\circ} \mathrm{C}$ in medium comprising glucose $0.1 \%$, peptone $1 \%$, yeast extract $0.02 \%(\mathrm{w} / \mathrm{v})$, $\mathrm{MgSO}_{4} 0.01 \%(\mathrm{w} / \mathrm{v}), \mathrm{CaCl}_{2} 0.5 \%\left(\mathrm{w} / \mathrm{v}\right.$ ), and $\mathrm{FeSO}_{4} .7 \mathrm{H}_{2} \mathrm{O} \quad 0.01 \%$

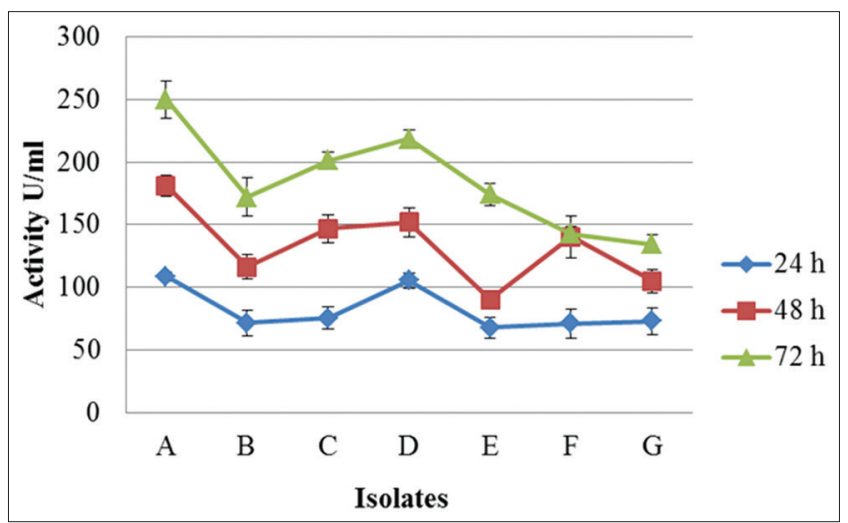

Fig. 1: Effect of incubation period on protease production (pH 7.0; $\left.37^{\circ} \mathrm{C}\right)$

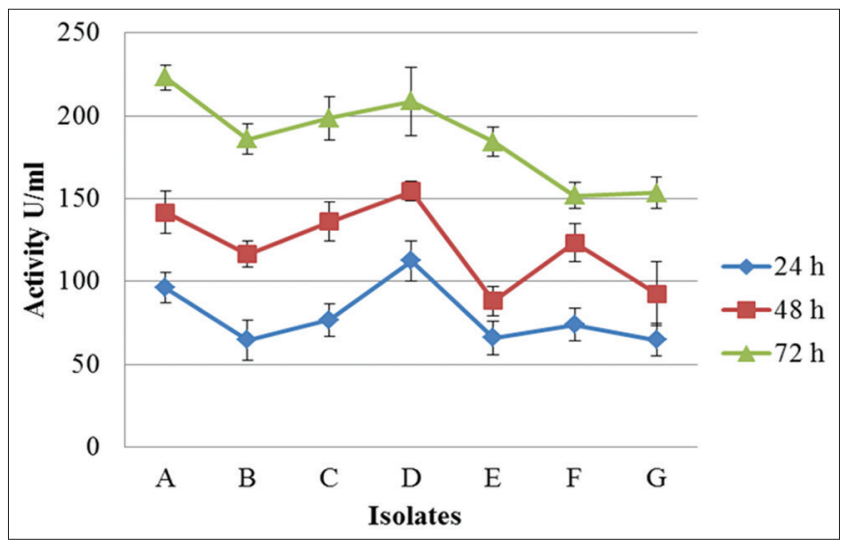

Fig. 2: Effect of incubation period on protease production (pH 9.0; $\left.37^{\circ} \mathrm{C}\right)$ 
$(\mathrm{w} / \mathrm{v}$ ), at $\mathrm{pH} 9.0$ for variable time intervals of 24,48 , and $72 \mathrm{~h}$. Values for the enzyme activity are presented as mean \pm SD of three sets of observations.

\section{Effect of agricultural residue}

For the commercial scale production of protease on an industrial level, use of the cheaper source is equally important apart from other physical and chemical parameters. Therefore, wheat bran, rice husk and maize powder were used as a substrate for the production of alkaline protease. The analysis of results showed that agricultural residues used alone also led to the production of the enzyme. Among them, wheat bran showed comparatively higher level of alkaline protease production. All isolates showed maximal activity at $72 \mathrm{~h}$ incubation period where isolate "A" produced higher enzyme activity $(35 \mathrm{U} / \mathrm{ml})$ using wheat bran as a sole source of the nutrient. The corresponding production of alkaline protease for " $\mathrm{C}$ " and " $\mathrm{D}$ " isolates was $(32 \mathrm{U} / \mathrm{ml})$ and $(27 \mathrm{U} / \mathrm{ml})$, respectively. Comparatively lower activity of the enzyme was noted for isolates "B" (23 U/ml) and "F" (18 U/ml). No significant activity of alkaline protease was observed using rice husk, chickpea, and maize powder, thereby concerned results are not shown (Fig. 4).

Production of alkaline protease was carried out by cultivating the isolates using minimal media (disodium hydrogen phosphate 3\%, potassium dihydrogen phosphate $1.5 \%$, ammonium chloride $0.5 \%$, sodium chloride $0.25 \%$, calcium chloride $0.001 \%$ ) with $1.0 \%(\mathrm{w} / \mathrm{v})$ of wheat bran, as a sole carbon source at $50^{\circ} \mathrm{C}$ for $72 \mathrm{~h}, \mathrm{pH}=9.0$. Values for the enzyme activity are presented as mean \pm SD of three independent experiments.

\section{Effect of variable $\mathbf{p H}$}

\section{Isolate " $A$ "}

$\mathrm{pH}$ is an important physical parameter required to maintain ionization status for active site amino acid residues thereby affecting the growth and subsequent yield of alkaline protease.

Influence of variable $\mathrm{pH}(7.0-10.0)$ on the production of alkaline protease was investigated using isolate " $\mathrm{A}$ " and "D." The production level of the enzyme was observed to increase with corresponding increase in the $\mathrm{pH}$ of production media from 7.0 to 9.0. In all cases, the maximal activity of the enzyme was obtained at $\mathrm{pH} 9.0$ for an incubation period of $24 \mathrm{~h} \mathrm{(129} \mathrm{U/ml),} 48 \mathrm{~h}(187 \mathrm{U} / \mathrm{ml})$, and $72 \mathrm{~h}(243 \mathrm{U} / \mathrm{ml})$. These results indicate alkaliphilic nature of protease originating from isolate "A." The yield of the enzyme was decreased with further increase in $\mathrm{pH}$ to 10.0. Thus, isolate "A" can grow and produce alkaline protease over a wide $\mathrm{pH}$ range from 7.0 to 10.0 (Fig. 5).

The activity of the enzyme from isolate " $\mathrm{A}$ " was measured at variable $\mathrm{pH}(7.0,8.0,9.0$, and 10.0$)$ at $50^{\circ} \mathrm{C}$ for 24,48 , and $72 \mathrm{~h}$ using casein as the substrate. Buffers used were acetate (4.0-6.0), phosphate (6.0-7.0), Tris- $\mathrm{HCl}$ (7.0-9.0), and glycine- $\mathrm{NaOH}$ (10.0-12.0). Values are presented as mean $\pm \mathrm{SD}$ of triplicates.

\section{Effect of carbon source}

Since isolate "A" gave maximal activity of alkaline protease under alkaline $\mathrm{pH}$ of 9.0 and at a higher temperature of $50^{\circ} \mathrm{C}$ indicating its alkaliphilic and thermophilic nature; further studies were carried out by selecting the same isolate.

Carbon plays a prime role during growth and production of desired metabolites by the microbial cell. Both types of carbon source as well as its concentration added to the production medium significantly affects the production of the extracellular enzyme. The effect of different carbon sources including mono-, di- and poly-saccharides such as maltose, glucose, starch, and lactose on the production of alkaline protease was analyzed. All the carbon sources supported growth and production of alkaline protease by selected isolate "A." The isolate responded to different carbon sources by showing variable yield of the enzyme. Among various carbon sources, maximum production of the protease was observed in the presence of glucose $(95 \mathrm{U} / \mathrm{ml})$ and

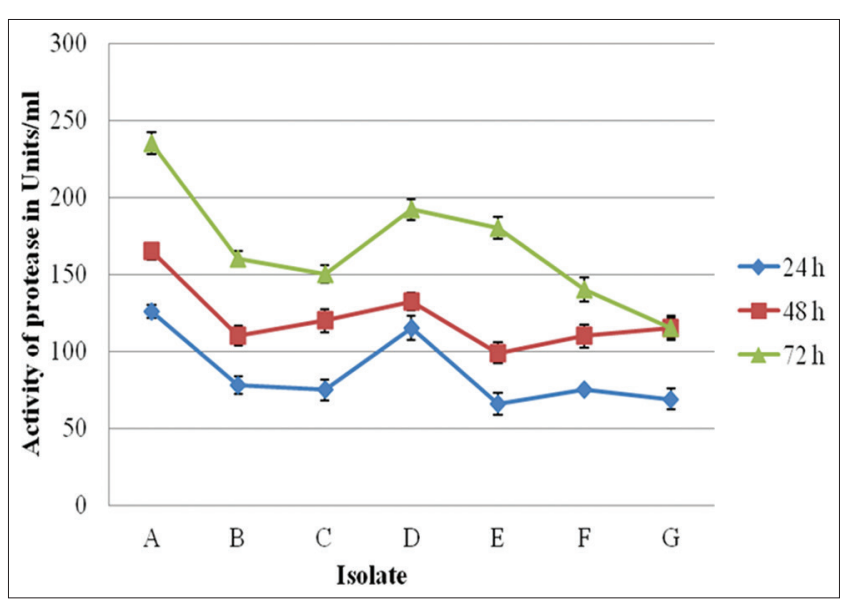

Fig. 3: Effect of incubation period on protease production ( $\mathrm{pH} 9.0$; $\left.50^{\circ} \mathrm{C}\right)$

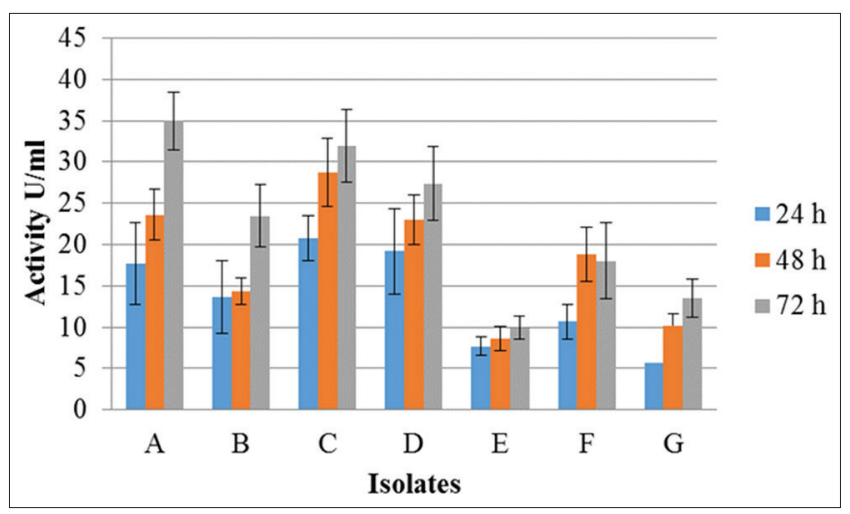

Fig. 4: Effect of wheat bran on the protease production (pH 9.0; $\left.50^{\circ} \mathrm{C}\right)$

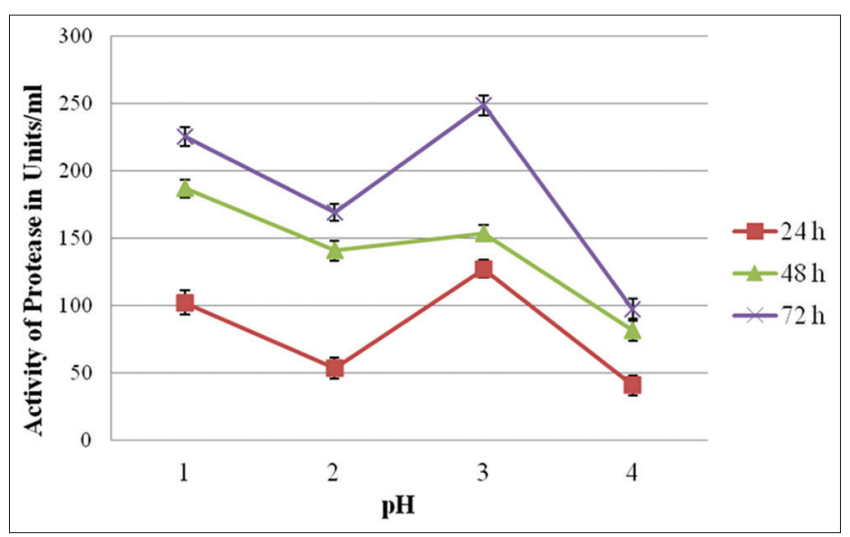

Fig. 5: Effect of variable $\mathrm{pH}$ on protease production from isolate " $\mathrm{A}$ "

maltose $(91 \mathrm{U} / \mathrm{ml})$. The production of enzyme was further decreased for starch and lactose by $10 \%$ showing $85 \mathrm{U} / \mathrm{ml}$ activity. Thus, glucose and maltose being simple and easily metabolizable sugars support maximal production. These results are in accordance with the results obtained for Bacillus sp. from different wastes [23]. The decrease in enzyme production in case of lactose and starch was observed due to their structural complexity accompanied by catabolite repression of protein biosynthesis (Fig. 6).

Production of alkaline protease was carried out by cultivating isolate " $\mathrm{A}$ " in the growth medium with $1 \%(\mathrm{w} / \mathrm{v})$ of different sugars at $50^{\circ} \mathrm{C}$ for 24 , 48 , and $72 \mathrm{~h}$. Values are given as mean \pm SD of triplicates. 
Effect of nitrogen source

Nitrogen source also affects metabolic processes of the cell significantly. In accordance with this, the effect of nitrogen on the production of alkaline protease was analyzed by growing bacterial isolate " $\mathrm{D}$ " in the production medium supplemented with variable nitrogen sources at $0.5 \%(\mathrm{w} / \mathrm{v})$ concentration. Bacterial cells grown using casein as a nitrogen source exhibited the higher activity of alkaline protease $(223 \mathrm{U} / \mathrm{ml})$ followed by yeast extract $(160 \mathrm{U} / \mathrm{ml})$. Production of the enzyme was reduced significantly for beef extract and peptone to $51 \%$ and $43 \%$, respectively. Thus results indicated that casein being an organic nitrogen source enhances maximum protease and also serves as an inducer for the production of the enzyme. Similar results were observed for alkaline protease isolated from Bacillus sp. (Fig. 7) [24,25].

Production of alkaline protease was carried out by cultivating isolate "A" in the growth medium with $1 \%(\mathrm{w} / \mathrm{v})$ of different organic nitrogen sources at $50^{\circ} \mathrm{C}$ for 24,48 , and $72 \mathrm{~h}$. Data represent mean $\pm \mathrm{SD}$ of three sets of observations.

\section{Effect of variable buffers on the enzyme activity (pH 9.0)}

Buffers components as weak acids and their corresponding salts of weak base can also affect the enzyme activity. From graph 8, it revealed that alkaline protease displayed higher activity for Tris $\mathrm{NaOH}$ buffer (154 U/ml). Comparatively, lower activity was observed in the presence of glycine-NaOH buffer $(75 \mathrm{U} / \mathrm{ml})$ followed by Borax buffer $(67 \mathrm{U} / \mathrm{ml})$. Use of carbonate-bicarbonate buffer, significantly lowered the activity to $43 \mathrm{U} /$ $\mathrm{ml}$. Thus, buffer components interact variably with proteins causing proton transfer or buffer component binding thereby inducing conformational changes resulting in the denaturation of protein (Fig. 8) [26].

Production of alkaline protease was carried out by cultivating isolate " $\mathrm{A}$ " in the growth medium with different buffers, $\mathrm{pH}=9.0$ at $50^{\circ} \mathrm{C}$ for $24 \mathrm{~h}$. Data represent mean \pm SD of three sets of observations.

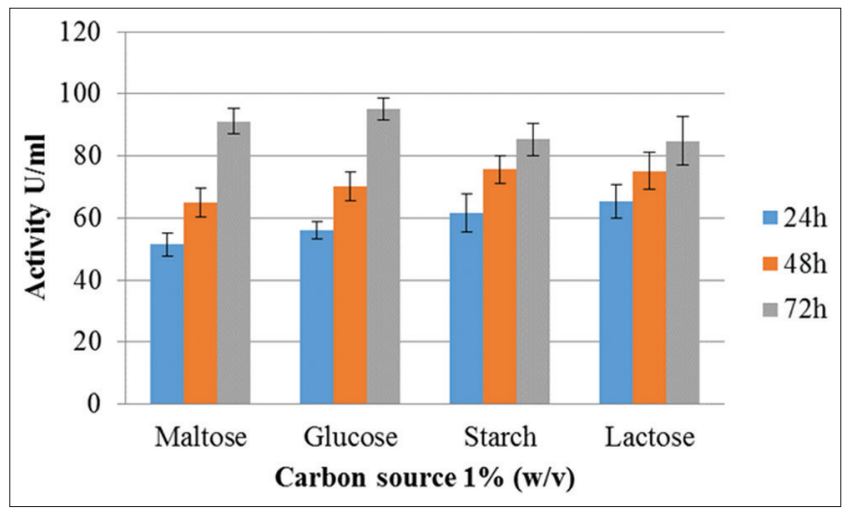

Fig. 6: Effect of carbon source on protease production from isolate " $\mathrm{A}$ "

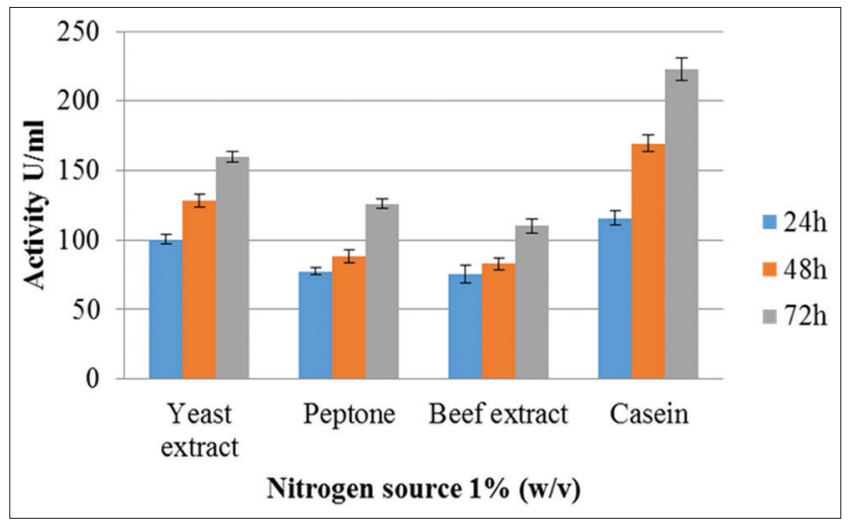

Fig. 7: Effect of nitrogen source on protease production from isolate " $\mathrm{A}$ "
Partial purification of enzyme by ammonium sulfate purification Alkaline protease present in the crude extract was purified by $80 \%$ saturation with ammonium sulfate leading to enhancement in the activity (190 U/ml) by 4\% (Fig. 9). The protease produced by Trichosporon japonicum was partially purified by the ammonium sulfate precipitation method with $60 \%$ saturation giving highest protease activity [27].

Purification of the enzyme was carried out using $80 \%$ saturation with ammonium sulfate followed by dialysis using Tris buffer $(0.02 \mathrm{M}$, $\mathrm{pH}$ 9.0). Data represent mean \pm SD of three sets of observations.

The observed specific activity of alkaline protease after ammonium sulfate purification was $169 \mathrm{U} / \mathrm{mg}$ indicating 35\% purification fold. Wide-ranging results of protease purification (4.25-200-fold) with various specific activities (13.34 $\mathrm{U} / \mathrm{mg}$ of protein) and \% recovery (2-21\%) have been described for different microbial species such as Bacillus licheniformis, Bacillus subtilis, and Bacillus megaterium (Fig. 10) [28-30].

Specific activity of the alkaline protease was analyzed before and after dialysis: Data represent mean \pm SD of three sets of observations

The alkaline protease was purified using DEAE-cellulose ion exchange chromatography technique. The bound proteins were eluted with $0.5 \mathrm{M} \mathrm{NaCl}$ in phosphate buffer of $\mathrm{pH}$ 7.0. The alkaline protease enzyme bound to DEAE-cellulose and eluted in fractions numbers 25-35 by applying step gradient of $0-0.5 \mathrm{M} \mathrm{NaCl}$. Thereby elution profile of enzyme displayed a single peak resulting in the formation of peak containing protease activity. The enzyme was purified up to 16 -fold as bound fraction of DEAE-cellulose column with $1928 \mathrm{U} / \mathrm{mg}^{-1}$ specific activity (Fig. 11). As per previous results regarding protease purification, the values of specific activities observed for different microbial species such as B. licheniformis, $B$. subtilis, and B. megaterium were $13.33-159381 \mathrm{U} / \mathrm{mg}$ of protein with $4.25-200$ purification fold $[28,29]$

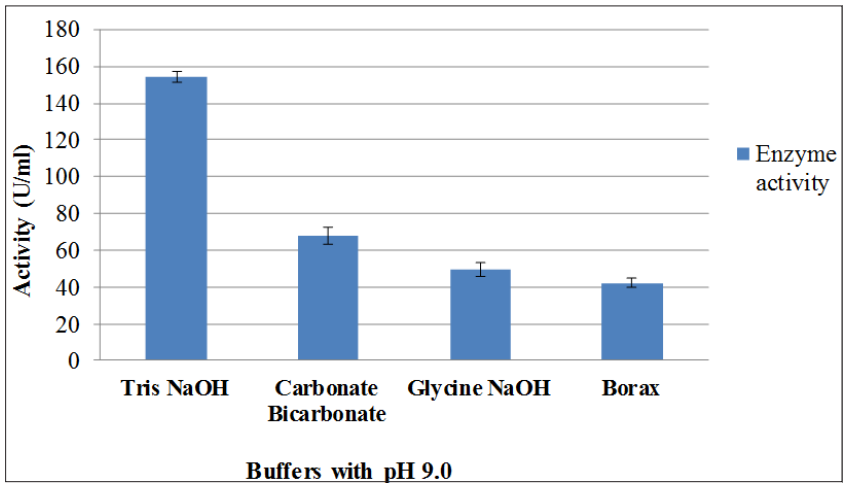

Fig. 8: Effect of buffers with variable pH on protease activity from isolate " $\mathrm{A}$ "

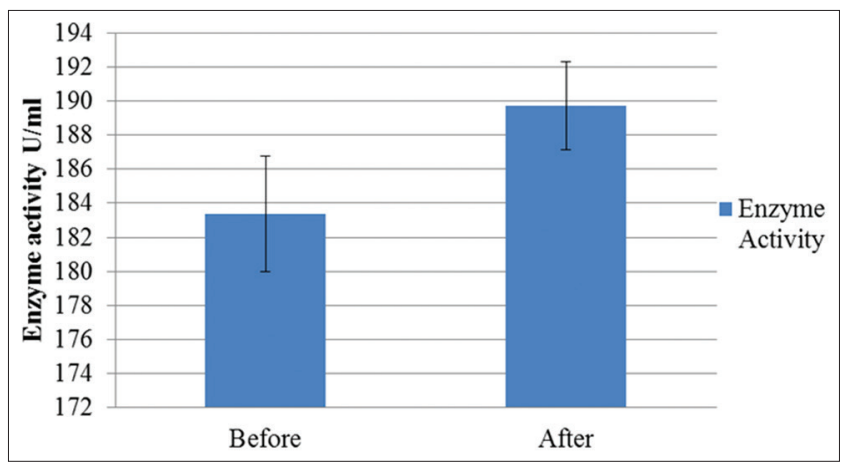

Fig. 9: Activity of enzyme before and after ammonium sulfate purification 
Chromatogram of the purified enzyme produced by isolate "A" using DEAE-cellulose ion exchange column with dimensions $1.5 \mathrm{~cm} \times 50 \mathrm{~cm}$ and a flow rate of $25 \mathrm{ml} / \mathrm{h}$. Fractions 25-35 containing the eluted enzyme confirmed alkaline protease activity (Table 2).

\section{Effect of organic solvents}

Stability of alkaline protease toward organic solvents revealed their commercial significance on industrial scale. In view of this effect of different water miscible and immiscible organic solvents on the activity of alkaline protease produced by isolate " $\mathrm{A}$ " was analyzed by incubating the enzyme along with organic solvents for $1 \mathrm{hr}$. The alkaline protease was found to be comparatively more stable in the presence of ethanol, methanol, and acetone with residual activity of $61.92 \%, 53.78 \%$, and $44.42 \%$, respectively. N-hexane and toluene caused greater inhibitory effect showing $25 \%$ and $29 \%$ residual activity for the enzyme. Organic solvents alter the catalytic mechanism by interfering the hydrogen bonding and hydrophobic interactions among active protein leading to unfavorable changes in dynamics and conformation [31]. Previous studies have reported organic solvent-tolerant strains from the genus Pseudomonas and Bacillus producing solvent stable enzymes (Fig. 12) [32,33].

Figure indicates stability of alkaline protease in the presence of organic solvents at $37^{\circ} \mathrm{C}$ for $1 \mathrm{~h}$. Residual protease activity was measured at $50^{\circ} \mathrm{C}$ for 30 minutes with $\mathrm{pH} 9.0$ using caseinolytic assay. The proteolytic activity measured without organic solvent was taken as control. Values are presented as mean $\pm \mathrm{SD}$ of three independent experiments.

\section{Effect of surfactants}

Stability of alkaline proteases toward surfactants enhances their potential in washing and destining technology making them compatible in the detergent manufacturing process. Stability of alkaline protease was analyzed by preincubating the enzyme in the presence of various surfactants for $1 \mathrm{~h}$ and the residual activity is presented in Fig. 13. The alkaline protease remained comparatively stable in the presence of $0.5 \%(\mathrm{w} / \mathrm{v})$ SDS and Triton-X-100 with the relative residual activity of $35 \%$ and $30 \%$, respectively. The reduction of the activity and stability of enzyme observed in the presence of SDS, a nonionic surfactant with 8\% of residual activity as revealed for several enzymes due to disruption of their structures after interaction with SDS [34]. The precipitation and subsequent inhibition of alkaline protease were observed in the presence of SDS observed. The results obtained are in accordance with Komarov et al. [35] where inhibition of pepsin by SDS was observed due to precipitation of the enzyme at isoelectric point. A reduction of $43 \%$ and $67 \%$ in the activity of pepsin after incubation with $1.4 \%$ SDS for 2 and $4 \mathrm{~h}$, respectively indicated unfolding of enzyme leading to its inactivation [36].

The alkaline protease from isolate " $\mathrm{A}$ " was preincubated with 0.5 $1 \%(\mathrm{w} / \mathrm{v}$ and $\mathrm{v} / \mathrm{v})$ of various surfactants (SDS, Triton- $\mathrm{x}-100$ and Tween-80) at $37^{\circ} \mathrm{C}$ for $1 \mathrm{~h}$. The residual enzyme activity was measured at $50^{\circ} \mathrm{C}$ for 30 minutes with $\mathrm{pH} 9.0$. The proteolytic activity measured without surfactant and oxidizing agent was taken as control. Values are presented as mean $\pm \mathrm{SD}$ of three sets of observations.

\section{Role of alkaline protease enzyme in the destaining process}

Alkaline protease is primarily employed as cleansing additives [37]. One of the major applications of alkaline protease includes removal of proteinaceous stains. The enzyme shows much reduction in the stain intensity compared to the detergent. Similarly, when the enzyme was applied along with the detergent, the effect of destaining was enhanced as compared to the treatment given using only distilled water or distilled water with detergent. As per earlier reports addition of alkaline protease to commercial detergents significantly increases washing performance and removal of blood stains [38]. The significant role of alkaline protease produced by isolate " $\mathrm{A}$ " in washing performance in addition to higher proteolytic activity and stability indicates its application as an additive in commercial detergents (Fig. 14).

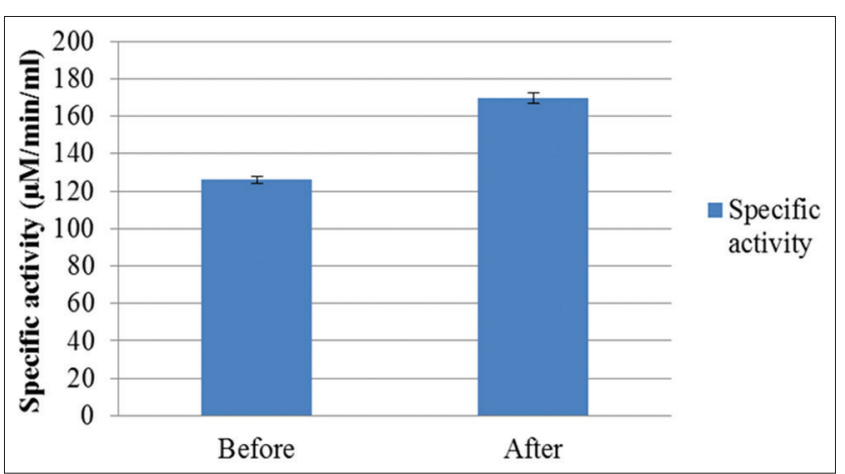

Fig. 10: Specific activity of alkaline protease

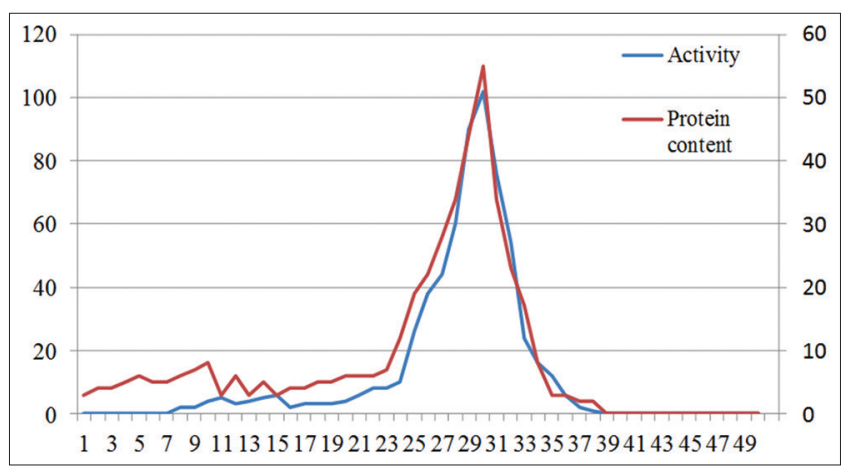

Fig. 11: Ion exchange chromatography of the alkaline protease using DEAE-cellulose

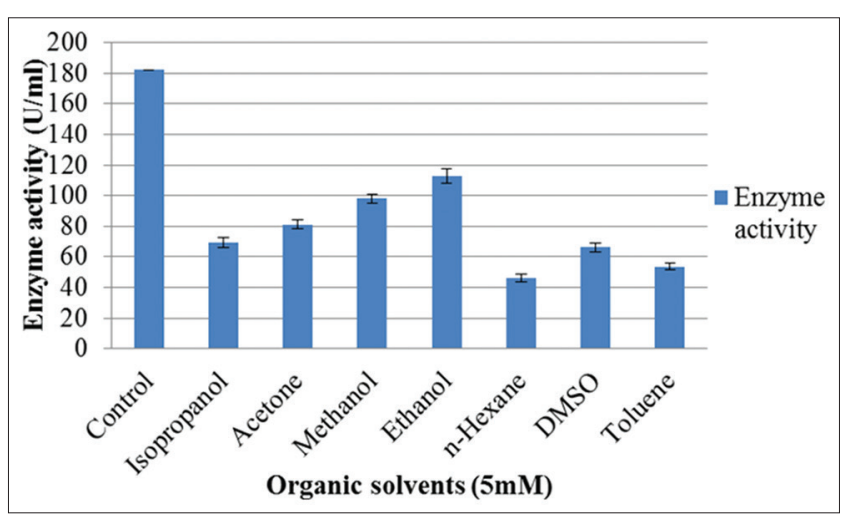

Fig. 12: Effect of solvents on the protease production from isolate "A"

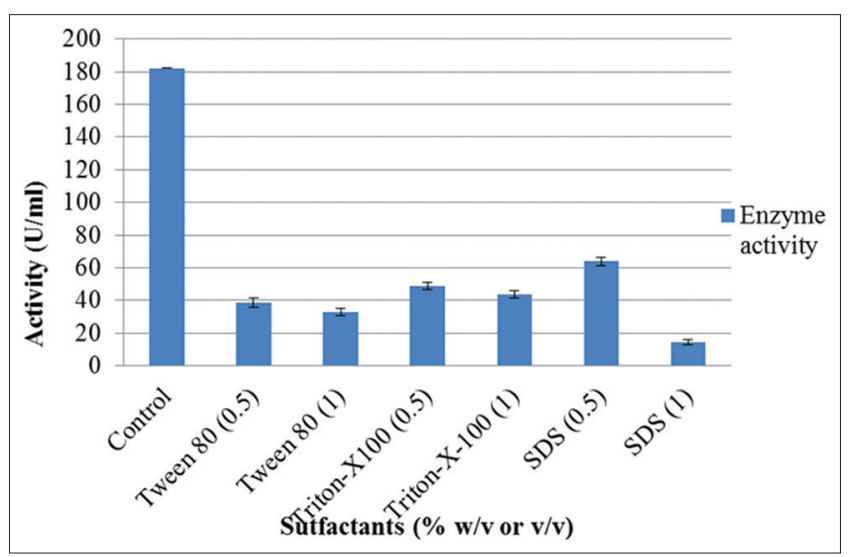

Fig. 13: Effect of surfactants on protease production from isolate " $\mathrm{A}$ " 
Table 2: Purification steps for the alkaline protease

\begin{tabular}{llllll}
\hline Purification steps & Total activity & Total protein (U/mL) & Specific activity (mg) & Purification fold (U/mg) & Yield (\%) \\
\hline Crude enzyme & 2749 & 22.4 & 127.72 & 1 & 100 \\
Ammonium sulfate precipitation & 1897 & 11.11 & 170.74 & 1.4 & 69 \\
DEAE-cellulose ion exchange & 2650 & 1.4 & 1928 & 16 & 96 \\
\hline
\end{tabular}

The alkaline protease was purified by 16 -fold with increase in specific activity

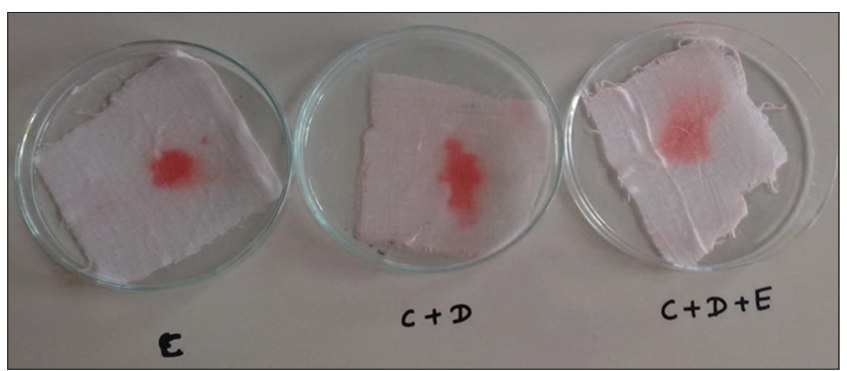

Fig. 14: Destaining of blood on cloth [C= Distilled water; $\mathrm{C}+\mathrm{D}=$ Detergent solution $(7 \mathrm{mg} / \mathrm{ml}$ ) and distilled water; $\mathrm{C}+\mathrm{D}+\mathrm{E}=$ Detergent solution along with alkaline protease]

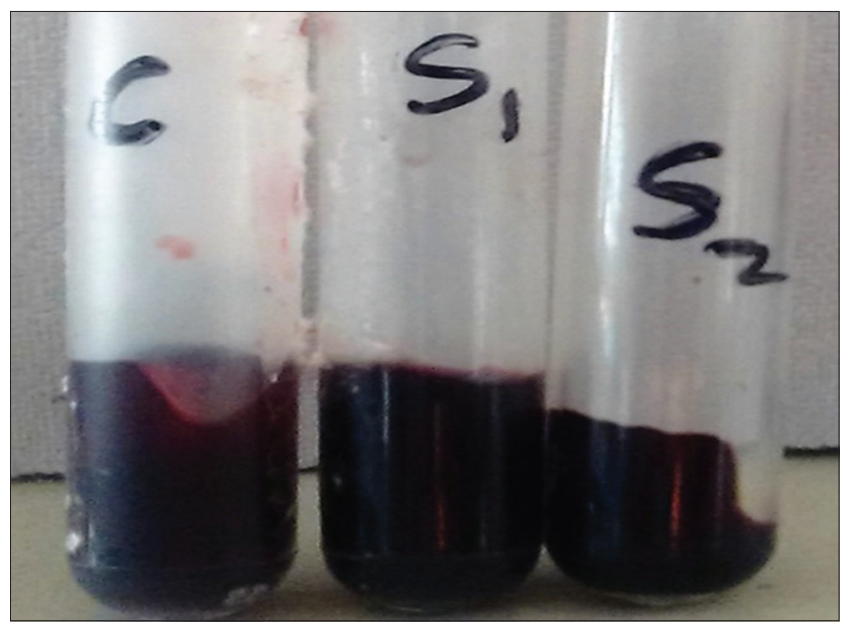

Fig. 15: Fibrinolytic action of the alkaline protease on blood $[\mathrm{C}=$ Blood clot + distilled water, $\mathrm{S} 1=$ Blood clot $+0.5 \mathrm{ml}$ enzyme S2 = Blood clot $+1 \mathrm{ml}$ enzyme]

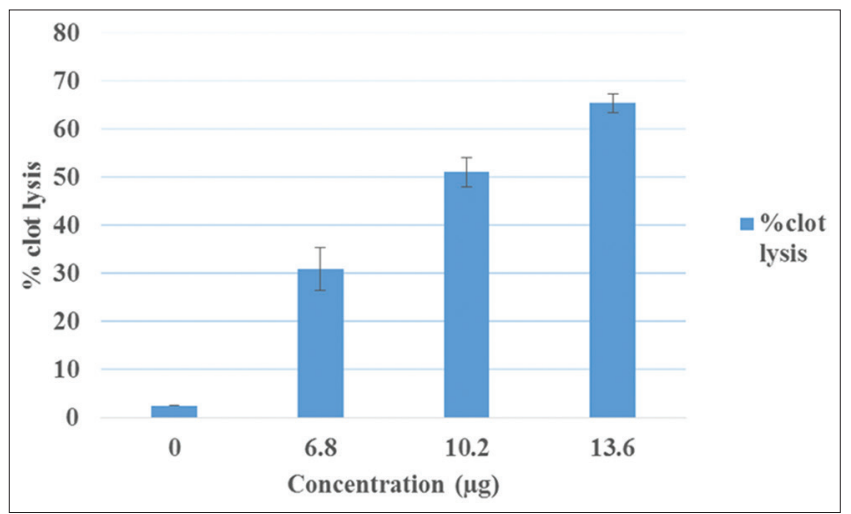

Fig. 16: Percent of clot lysis by alkaline protease enzyme from isolate " $A$ "

$\mathrm{C}=$ Control containing distilled water showing negligible stain removal (without protease), $\mathrm{C}+\mathrm{D}=$ Detergent solution $(7 \mathrm{mg} / \mathrm{ml})$ and distilled water showing partial stain removal, $\mathrm{C}+\mathrm{D}+\mathrm{E}=$ Detergent solution along with alkaline protease showing considerable stain removal.

\section{Blood clot dissolution studies}

The alkaline protease showed positive results for the dissolution of blood clot where the significant results were observed using higher concentration of enzyme (Fig. 15). Dissolution of blood clot indicates the fibrinolytic action of the enzyme. The mechanism involves hydrolysis of cross-links between fibrin molecules with disruption of the structural integrity of blood clot due to proteolytic action of the enzyme. The ability of alkaline protease in converting insoluble forms of blood clot to soluble form designates its clinical and medicinal applications in the thrombolytic drug. Similar results were obtained for the alkaline protease from B. licheniformis B18 for dissolution of blood clot $[39,40]$. Fibrinolytic enzymes from microbial sources, like, nattokinase, offer great promise in the management (7-8 h) and support of healthy blood circulation. It lyses fibrin directly ad changes prourokinase to urokinase and increase tissue plasminogen activator, which increases our plasmin. Nattokinase lessens excessive coagulation and thus improves circulation, increasing oxygen flow to tissues (Fig. 15) [41].

Percentage of clot lysis corresponds to the amount of the enzyme added. Data presented reveals mean \pm SD of three sets of observations.

\section{CONCLUSION}

Seven thermophilic bacterial isolates derived from soil and water samples collected from hot water springs exhibited extracellular protease production as observed from zone of clearance on skim milk agar ( $\mathrm{pH}$ 7.0). Optimal time duration for the protease production by all thermophilic isolates observed was $72 \mathrm{~h}$. The ability of these isolates to produce protease at $\mathrm{pH} 9.0$ and at a higher temperature of $50^{\circ} \mathrm{C}$ also verified their alkaliphilic and thermophilic nature. Isolate " $\mathrm{A}$ " was found to be promising one that exhibited higher level of alkaline protease production $(235 \mathrm{U} / \mathrm{ml})$ at $\mathrm{pH} 9.0$ and at a temperature of $50^{\circ} \mathrm{C}$. Use of glucose as a carbon source decreased the protease production showing $95 \mathrm{U} / \mathrm{ml}$ activity. However using casein as a source of nutrient resulted in significant increase in the activity of alkaline protease $(231 \mathrm{U} / \mathrm{ml})$. Thus, casein acts as an ideal inducer for the production of alkaline protease. Using wheat bran as a sole nutritional source, isolate "A" displayed considerable enzyme activity of $32 \mathrm{U} / \mathrm{ml}$. The enzyme was purified by using anion exchange chromatography, eluted as a single peak by applying stepwise gradient of $0.5 \mathrm{M} \mathrm{NaCl}$. The enzyme was purified by 16 -fold with $1928 \mathrm{U} / \mathrm{mg}^{-1}$ specific activity. The activity of alkaline protease was found to be comparatively stable in the presence of organic solvents such as acetone and methanol showing 44\%, 53\%, residual activity, respectively. Similarly, enzyme was also stable in the presence of $0.5 \%(\mathrm{w} / \mathrm{v})$ SDS as a surfactant showing $35 \%$ residual activity. These results indicate industrial significance for isolate alkaline protease.

\section{ACKNOWLEDGMENT}

The authors are thankful to Dr. D.Y. Patil Vidyapeeth, Dr. D.Y. Patil Biotechnology and Bioinformatics Institute, Pune for financial assistance.

\section{REFERENCES}

1. Gupta R, Beg QK, Lorenz P. Bacterial alkaline proteases: Molecular approaches and industrial applications. Appl Microbiol Biotechnol 2002;59(1):15-32.

2. Adinarayana K, Ellaiah P. Response surface optimization of the critical medium components for the production of alkaline protease by a newly isolated Bacillus sp. J Pharm Pharm Sci 2002;5(3):272-8. 
3. Beg QK, Gupta R. Purification and characterization of an oxidationstable thiol-dependent serine alkaline protease from Bacillus mojavensis. Enzyme Microb Technol 2003;32:294-4.

4. Jaswal RK, Kocher GS. Partial characterization of a crude alkaline protease from Bacillus cirulans and its detergent compatibility. Internet J Microbiol 2007;4(1):1-9.

5. Betigeri SS, Neau SH. Immobilization of lipase using hydrophilic polymers in the form of hydrogel beads. Biomaterials 2002;23(17):3627-36.

6. Denizci AA, Kazan D, Abeln EC, Erarslan A. Newly isolated Bacillus clausii GMBAE 42: An alkaline protease producer capable to grow under higly alkaline conditions. J Appl Microbiol 2004;96(2):320-7.

7. Jain D, Pancha I, Mishra SK, Shrivastav A, Mishra S. Purification and characterization of haloalkaline thermoactive, solvent stable and SDSinduced protease from Bacillus sp.: A potential additive for laundry detergents. Bioresour Technol 2012;115:228-36.

8. Rabab O. Production of keratinases from Nocardiopsis $\mathrm{sp}$. 28ror as a novel Iraqi strain. Asian J Pharm Clin Res 2017;10(4):160-8.

9. Jellouli K, Bougatef A, Manni L, Agrebi R, Siala R, Younes I, et al. Molecular and biochemical characterization of an extracellular serineprotease from Vibrio metschnikovii J1. J Ind Microbiol Biotechnol 2009;36(7):939-48.

10. Kumar RS, Ananthan G, Prabhu AS. Optimization of medium composition for alkaline protease production by Marinobacter sp. GA CAS9 using response surface methodology - A statistical approach. Biocatal Agric Biotechnol 2014;3:191-7.

11. Tunga R, Shrivastava B, Banerjee R. Purification and characterization of a protease from solids state cultures of Aspergillus parasiticus. Process Biochem 2003;38(11):1553-8.

12. Abhas KM, Ishita S, Prakash CB, Pratima R. Extracellular alkaline protease producing halo-alkalitolerant bacteria isolated from marine coasts of Odisha. Int J Pharm Pharm Sci 2016;8(5):379-86.

13. Sankari D, Khusro A. Biochemical, molecular characterization and sequence analysis of keratinase producing novel strain of Bacillus licheniformis isolated from poultry farm. Int $\mathrm{J}$ Pharm Pharm Sci 2014;6(8):457-61

14. Sonnleitner B, Fiechter A. Bacterial diversity in thermophilic aerobic sewage sludge I. Active biomass and fluctuations. Eur J Appl Microbiol Biotechnol 1983;18:47-51.

15. Rao MB, Tanksale AM, Ghatge MS, Deshpande VV. Molecular and biotechnological aspect of microbial proteases. Microbiol Mol Biol Rev 1998;62(3):597-635

16. Zeikus JG, Vieille C, Sachiko A. Thermozymes: Biotechnology and structure-function relationship. Extremophiles 1998;2(3):179-83.

17. George SP, Ahmad A, Rao MB. Studies on carboxymethyl cellulase produced by an alkalothermophilic actinomycete. Bioresour Technol 2001;77(2):171-5

18. Haddar A, Agrebi R, Bougatef A, Hmidet N, Sellami-Kamoun A, Nasri M. Two detergent stable alkaline serine-proteases from Bacillus mojavensis A21: Purification, characterization and potential application as a laundry detergent additive. Bioresour Technol 2009;100(13):3366-73

19. Heck JX, Hertz PF, Ayub MA. Cellulose and xylanase production by isolated amazon Bacillus strains using soybean industrial residue based solid-state cultivation. Braz J Microbiol 2002;33(3):213-8.

20. Amritkar N, Kamat M, Lali A. Expanded bed affinity purification of bacterial $\alpha$-amylase and cellulose on composite substrate analoguecellulose matrices. Process Biochem 2004;39(5):565-70.

21. Gomaa EZ. Optimization and characterization of alkaline protease and carboxymethyl-cellulase produced by Bacillus pumillus grown on Ficus nitida wastes. Braz J Microbiol 2013;44(2):529-37.

22. Kumar PK, Mathivanan V, Karunakaran M, Renganathanand S, Sreenivasan RS. Studies on the effects of $\mathrm{pH}$ and incubation period on protease production by Bacillus sp. Using groundnut cake and wheat bran. Indian J Sci Technol 2008;1(4):1-4.

23. Boominadhan U, Rajakumar R, Sivakumaar PK, Joe MM. Optimization of protease enzyme production using Bacillus sp. Isolated from different wastes. Bot Res Int 2009;2(2):83-7.

24. Dhara D, Trupti KV. Alkaline protease production by thermophilic and alkalophilic halotolerant Bacillus sp. Strain TD: A promising enzyme producer for biotechnological application. DAMA Int 2014;3(1):12-7.

25. Kumar RS, Prabhu D, Shankar T, Sankaralingam S, Anandapandian KT. Optimization of alkalophilic protease production by Pseudomonas aeruginosa isolated from the gut of Penaus monodon. World J Fish Mar Sci 2011;3(5):371-5.

26. Alberty RA, Bock RM. Alteration of the kinetic properties of an enzyme by the binding of buffer, inhibitor, or substrate. Proc Natl Acad Sci U S A 1953;39(9):895-900.

27. Venkat KS, Ashok R, Joshua RN. Screening, media optimization and partial purification of protease by Trichosporon japonicum VITVK1. Int J Pharm Pharm Sci 2014;7(2):187-91.

28. Guangrong VH, Tiejing Y, Po H, Jinxing J. Purification and characterization of a protease from thermophilic Bacillus strain HS08. Afr J Biotechnol 2006;5(24):2433-8

29. Kim WJ, Kim SM. Purification and characterization of Bacillus subtilis JM-3 protease from anchovy sauce. J Food Biochem 2005;29(5):591-10.

30. Yossan S, Reungsang A, Yasuda M. Purification and characterization of alkaline protease from Bacillus megaterium isolated from Thai fish sauce fermentation process. Sci Asia 2006;32:377-83.

31. Barberis S, Quiroga E, Morcelle S, Priolo N, Luco JM. Study of phytoproteases stability in aqueous-organic biphasic systems using linear free energy relationships. J Mol Catal B Enzym 2006;38:95-103.

32. Geok LP, Razak CN, Rahman RN, Basri M, Salleh AB. Isolation and screening of an extracellular organic solvent-tolerant protease producer. Biochem Eng J 2003;13(1):73-7.

33. Ghorbel BA, Sellami-Kamoun MN. Stability studies of protease from Bacillus cereus BG1. Enzyme Microb Technol 2003;32(5):513-8.

34. Otzen DE, Oliveberg M. Burst-phase expansion of native protein prior to global unfolding in SDS. J Mol Biol 2002;315(5):1231-40.

35. Komarov SA, Siplet H, Shay H. A study of the effects and mechanism of action of sodium dodecyl sulphate on gastric secretion in rats. $\mathrm{Br} \mathrm{J}$ Pharmacol Chemother 1950;5(1):1-8

36. Nelson $\mathrm{C}$. The binding of detergents to proteins. I. The maximum amount of dodecyl sulfate bound to proteins and the resistance to binding of several proteins. J Biol Chem 1971;246(12):3895-901.

37. Aishwarya M, Swati K, Arvind S, Meenakshi SM. Production, characterization and purification of alkaline protease from Alcaligenes sp., And its application in detergent industry. Asian J Pharm Clin Res 2013;6(4):152-5

38. Arlumani M, Aparanjini K, Vasanthi K, Arumugam P, Arivuchelvi P, Kalaichelvan PT. Purification and partial characterization of serine protease from thermostable alkalophilic Bacillus laterosporus-Ak1. World J Microbiol Biotechnol 2007;23(4):475-81

39. Saba I, Qazi PH, Rather SA, Dar RA, Qadri QA, Ahmad N, et al. Purification and characterization of a cold active alkaline protease from Stenotrophomonas sp., Isolated from Kashmir, India. World J Microbiol Biotechnol 2012;28(3):1071-9.

40. Shankar S. Purification and Characterization of Alkaline Protease from a Bacillus licheniformis B18. Ph.D. Thesis; 2010.

41. Rajani GG, Nirmala S, Narendar SS. Fibrinolytic enzyme from Bacillus amyloliquefaciens: Optimisation and scale up studies. Int J Pharm Pharm Sci 2014;6(10):370-8 